SNJEŽANA MILIVOJEVIĆ

Univerzitet u Beogradu, Fakultet političkih nauka, Beograd

DOI 10.5937/kultura1235285M

UDK 070(497.11)"2010/2011"

originalan naučni rad

\title{
NISKEPLATEIVISOKA
}

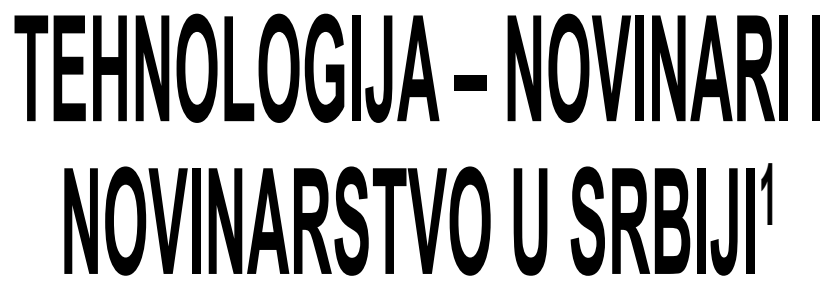

Sažetak: U ovom tekstu se razmatraju osnovni nalazi istraživanja „Profesija na raskršću - novinarstvo na pragu informacionog društva", koje je realizovao Centar za medije i medijska istraživanja Fakulteta političkih nauka u Beogradu, u periodu od jula 2010. do juna 2011. godine. ${ }^{2}$ Cilj projekta je bio da istraži društvene, ekonomske i tehnološke odlike novinarske zajednice u Srbiji, kao i njene kapacitete da odgovori na izazove sa kojima se profesija suočava u uslovima globalnih medijskih promena i domaćih tranzicionih procesa. Rezultati istraživanja upućuju na zaključak da je novinarstvo u Srbiji u svojevrsnom vakuumu i da zaglavljeno između odložene tranzicije i informacionog društva, veoma sporo mobiliše svoje resurse kao odgovor na dolazeće profesionalne izazove.

Ključne reči: budućnost novinarstva, novinarstvo u Srbiji, tehnološki izazovi u novinarstvu, društveno-ekonomski položaj novinara

Novinarska profesija nalazi se na jednoj od najozbiljnijih prekretnica u svojoj istoriji, koja se često opisuje kao "kriza" ili

1 Tekst prof. dr Snježane Milivojević Niske plate visoka tehnologija - novinari i novinarstvo u Srbiji je, zbog tehničkog propusta redakcije, objavljen bez fusnota i odgovarajućih odrednica u 132. broju časopisa. Uredništvo i redakcija časopisa Kultura želi ovom prilikom da uputi izvinjenje autorki prof. dr Snježani Milivojević i svim uglednicima koje je autorka citirala u tekstu, a čije su odrednice izostale. Zato koristimo priliku da, naknadno, u ovom broju tekst objavimo u celini.

2 Projekat je realizovan u okviru Regionalnog programa podrške istraživanjima u oblasti društvenih istraživanja na Zapadnom Balkanu (RRPP), koji vodi Univerzitet u Friburgu, uz finansijsku podršku Švajcarske agencije za razvoj i saradnju (SDC). Mišljenja izneta u ovom tekstu su mišljenja autora i ne predstvaljaju nužno mišljenja SDC i Univerziteta u Friburgu. 


\section{SNJEŽANA MILIVOJEVIĆ}

čak "smrt” novinarstva. Ovaj „krizni narativ“ je posebno uznemirujući kada se ima u vidu da novinarstvo spada među najznačajnije institucije demokratskog društva. Sumorni tonovi su u suprotnosti i sa optimizmom i očekivanjima koja prate razvoj informacionog društva. Moglo bi se desiti da u doba informacionog obilja i brzog proboja informaciono-komunikacionih tehnologija u sve sfere života, novinarstvo kao "obaveštavanje o događajima, okolnostima ili ličnostima od mogućeg značaja ili interesa za javnost, zasnovano na informacijama za koje se veruje da su pouzdane" ubrzo bude prevaziđeno. ${ }^{3}$ Razlog za radikalno preispitivanje profesije ovoga puta su temeljne i paralelne tehnološke, ekonomske i društvene promene koje predstavljaju ozbiljne izazove za savremeno novinarstvo.

Prvu i sasvim novu grupu izazova donosi tehnološki razvoj. "Nova medijska ekologija" obuhvata veliki dijapazon usluga, platformi i novih vidova komunikacija kojima novinarstvo mora da se prilagodi. Naravno, svi mediji su jednom bili novi, tehnološke promene su uvek bile izazov, ali nikada takvog intenziteta kao što se to desilo dolaskom interneta u medijsku porodicu. $\mathrm{U}$ društvima koja prelaze "iz industrijskog u informaciono doba" kompleksnost tehnoloških promena predstavlja jedinstveno i sasvim novo okruženje za novinarstvo.

Drugi ključni izazov dolazi sa ekonomskim aspektima informacionog društva. Sve prisutnije pitanje "ko će platiti za vest" ugrožava tradicionalni ekonomski model novinarstva koji je funkcionisao tokom čitavog XX veka. Sa novcem koji se od proizvođača sadržaja polako seli u ruke ponuđača sadržaja, stari biznis model novinarstva zasnovan na industriji oglašavanja se raspada, a njegova prva žrtva mogla bi biti upravo "vest". ${ }^{4}$ Potrebni su novi načini finansiranja proizvodnje vesti kako bi se amortizovali dalekosežni efekti narastajuće kulture "besplatnih informacija" karakteristične za informaciono društvo. Internet ekonomija je otvorila nove horizonte za medije, ali je i nepovratno transformisala medijsko poslovanje, dovodeći novinarstvo u situaciju koja se teško može popraviti. Aktuelna globalna ekonomska kriza samo dodatno pojačava problem slabeći medijsku industriju i ostavljajući novinare bez posla. Njena silovitost zamaglila je dublje restrukturiranje koje se istovremeno dešava $u$ osnovi medijske industrije.

3 McQuail D., Journalism as a public occupation: alternative images, in: Democracy, Journalism and Technology: New Developments in an Enlarged Europe, eds. Carpentier N. et al., Tartu University Press, Tartu 2008, str. 48..

4 Currah A., What's Happening to Our News: An investigation into the likely impact of the digital revolution on the economics of news publishing in the UK, Oxford 2009, str. 11-17. 


\section{SNJEŽANA MILIVOJEVIĆ}

Treće, informaciono društvo donosi suštinske promene u širem društvenom i kulturnom okruženju. Novi mediji ne samo da pružaju nove mogućnosti u plasmanu informacija, već omogućuju i pojavu novih aktera, spajaju stare ili stvaraju nove forme javne komunikacije. Konvergencija, interaktivnost, mobilnost i lako dostupne informacije povezane sa građanskim aktivizmom menjaju i tradicionalnu ulogu medija kao "četvrtog staleža". Kolokvijalnim rečnikom, od institucija koje informišu, zabavljaju i obrazuju, mediji se sve više pretvaraju u institucije koje informišu, zabavljaju i povezuju. Ta nova uloga transformiše medije u "peti stalež", uključujući široku lepezu aktera koji iz pozicije "građanskog novinarstva" ili u ulozi proizvođača sadržaja postaju moćni „umreženi pojedinci“. ${ }^{5}$ Medijska publika se pretvara u velikog, interaktivnog, mobilnog i individualizovanog aktera medijske scene, koji i sam postaje deo „staleža“. Medijska politika, ekonomija i kultura menjaju se tolikom brzinom i tako temeljno da zahtevaju preispitivanje i samog koncepta medija. ${ }^{6}$

Ove tri grupe izazova imaju karakter jedinstvenih (tehnoloških), cikličnih (ekonomskih) i dugoročnih (društvenih) promena koje se dešavaju istovremeno. ${ }^{7}$ Postoje određene regionalne razlike, ali se, pod njihovim uticajem, svuda širom demokratskog sveta novinarstvo radikalno menja. Zbog toga su i akademske i profesionalne debate o budućnosti novinarstva veoma rasprostranjene, česte i glasne. U demokratskim društvima sa dugom tradicijom medijskih sloboda, ova debata se fokusira na tehnološke promene i aktuelnu ekonomsku krizu. Zemlje Centralne i Istočne Evrope, u kojima je tranzicija uspešno završena, još pokušavaju da pronađu svoje mesto na mapi. ${ }^{8}$ Njihovi problemi slični su problemima drugih zemalja članica Evropske unije, iako u njihovim medijskim politikama često dolazi do epizoda koje na scenu vraćaju faktore političkih uticaja i pritisaka. ${ }^{9}$

Na Zapadnom Balkanu, ti izazovi su dodatno naglašeni dugotrajnom tranzicijom i slabom tradicijom novinarskog profesionalizma. Kako pokazuju novije komparativne studije, mediji u

5 Dutton W. H., The Fifth Estate Emerging through the Network of Networks, Prometheus, Vol. 27, No.1, 2009, str. 1-15.

6 Jakubowicz K., A new notion of media?, Council of Europe, Reykjavik 2009, str. 19.

7 Levy D. i Nielsen R. K., The Changing Business of Journalism and its Implications for Democracy, Oxford 2010, str. 4.

8 Jakubowicz K. i Sukosd M., Finding the Right Place on the Map, Bristol UK, Chicago USA 2008, str. 102.

9 Hume E., Cought in the Middle: Central and Eastern European Journalism at a Crossroads, Washington 2011, str. 11. 


\section{SNJEŽANA MILIVOJEVIĆ}

regionu dele ključne panevropske tendencije kao što su tehnološka konvergencija, koncentracija vlasništva i fragmentacija publike. ${ }^{10}$ Međutim, u ovdašnjim tranzicionim i postkonfliktnim društvima, oni se suočavaju i sa dodatnim problemima i dugotrajnim iscrpljivanjem u političkim i ideološkim sukobima. Zbog toga u mnogim od ovih društava, razmere promena u savremenom novinarstvu još uvek nisu ni postale društvena tema.

U Srbiji, zakasnela i komplikovana tranzicija stvorila je izrazito nepovoljan ambijent i za medijsku industriju i za novinare. Dugotrajnim odlaganjem stvoreno je okruženje u kojem većina ranih tranzicionih ciljeva još uvek nije ostvarena, a nakon deset godina ni prvi talas tranzicije nije dovršen. Neuspešna privatizacija, rastuća koncentracija vlasništva, razvoj medijskog tržišta i ekonomska kriza paralelno oblikuju svet medija. Informaciono društvo je u veoma ranoj fazi razvoja. Prema zvaničnoj statistici iz 2009. godine, pristup internetu ima 36,7\% domaćinstava, a $56.4 \%$ populacije nikada nije koristilo internet. ${ }^{11}$ Ali prema podacima Međunarodne unije za telekomunikacije (ITU), Srbija je među prvih 40 zemalja u svetu po indeksu razvoja informacionokomunikacionih tehnologija u 2010. godini. Takođe, dublje društvene i kulturne promene, kao što su brza feminizacija novinarske profesije i novi rodni odnosi koje ona donosi, otvaraju sasvim nova pitanja unutar profesionalne zajednice.

Prvobitni momentum posle 1989. godine da se novinarstvo profesionalizuje i oslobodi političke kontrole bio je veoma snažan. ${ }^{12}$ Međutim, ovaj cilj je potisnut dominacijom ratne propagande i govora mržnje tokom devedesetih, kao i isticanjem drugih, sistemskih prioriteta tokom 2000-tih. Takođe, tada proklamovani profesionalni ideali stvoreni su u okviru epohe "visokog modernizma" kada je bilo savršeno jasno da su ciljevi kojima se teži - profesionalna autonomija, služenje javnom interesu, pravo na izveštavanje i objektivnost. ${ }^{13}$ Dvadeset godina kasnije, sve je mnogo složenije. Lekcije iz tranzicije potvrđuju da mediji nisu nužno samo promoteri demokratije i da se novinarstvo slobodno od političkih i ekonomskih uticaja veoma teško razvija.

10 Television across Europe: more channels less independence, Budapest 2008, str. 18.

11 Upotreba informaciono-komunikacionih tehnologija u Republici Srbiji 2009. godine, Republički zavod za statistiku Srbije, dostupno na: http://www. slideshare.net/Shejla/upotreba-informacionp-komunikacionih-tehnologija-urepublici-srbiji-2009

12 Milivojević S., Novinarski profesionalizam: Granice medijske autonomje, Gledišta 1-6, 1993, str. 87-89.

13 Hallin D. C., The Passing of the 'High Modernism' of American Journalism, Journal of Communication, 42:3 1992, str. 15. 


\section{SNJEŽANA MILIVOJEVIĆ}

Novije akademske studije medijskog razvoja ukazuju na potrebu drugačijeg pristupa medijskim temama u zemljama slabe ili nekonsolidovane demokratije. Umesto pitanja kako mediji mogu da doprinesu demokratizaciji, one sugerišu postavljanje pitanja kakva demokratija je potrebna da bi mediji mogli da ostvaruju svoju demokratsku ulogu. ${ }^{14}$ Međutim, u oba pristupa, kvalitetno novinarstvo ostaje ključ ostvarivanja medijske uloge.

\section{O istraživanju}

U ovom tekstu se razmatraju osnovni nalazi istraživanja „Profesija na raskršću - novinarstvo na pragu informacionog društva" koje je realizovao Centar za medije i medijska istraživanja Fakulteta političkih nauka u Beogradu u periodu od jula 2010. do juna 2011. godine. ${ }^{15}$ Cilj projekta je bio da istraži društvene, ekonomske i tehnološke odlike novinarske zajednice u Srbiji, kao i njene kapacitete i da odgovori na izazove sa kojima se profesija suočava u uslovima globalnih medijskih promena i domaćih tranzicionih procesa. Glavna hipoteza istraživanja bila je da novinarstvo u Srbiji ne raspolaže adekvatnim resursima da odgovori na aktuelne tehnološke, ekonomske i socijalne izazove koji radikalno menjaju novinarsku profesiju.

Istraživanje je obavljeno kombinacijom kvalitativnih (anketno istraživanje) i kvantitativnih (fokus grupni intervju) metoda. Anketno istraživanje obavljeno je sa dve odvojene grupe ispitanika, jedno na uzorku od 260 novinara i urednika i drugo na uzorku od 51 vlasnika i direktora medija, kako bi se obuhvatili različiti članovi profesionalne zajednice. Anketa je najvećim delom sprovedena elektronskim upitnikom sa novinarima registrovanim $u$ najvećoj profesionalnoj bazi novinari.rs, koju je 2009. godine postavilo Nezavisno udruženje novinara Srbije.

U drugoj fazi obavljeni su fokus grupni intervjui sa 30 novinara, izabranih po istim kriterijumima po kojima su stratifikovani uzorci za anketno istraživanje (teritorija, vrsta medija, pol). Dve fokus grupe održane su sa novinarima iz Beograda i po jedna sa novinarima iz Vojvodine (u Novom Sadu) i iz Centralne Srbije (u Kragujevcu). U svakoj od njih bio je jednak broj novinara $\mathrm{i}$ novinarki, mlađih i starijih, po dve trećine zaposlenih u elektronskim i trećina u štampanim i drugim medijima. Pri izboru učesnika vodilo se računa i o razlikama u tipu vlasništva, uređivačkoj politici i tiražu/gledanosti medija. Diskusija u fokus

14 Zielonka J. i Mancini P., A media map of Central and Eastern Europe: Executive Summary, 2011, http://mde.politics.ox.ac.uk/images/stories/ summary_mdcee_2011.pdf.

15 Projekat je realizovao tim u sastavu: mr Marijana Matović, mr Aleksandra Ugrinić, mr Ana Milojević, mr Maja Raković, dr Miroljub Radojković i dr Snježana Milivojević. 


\section{SNJEŽANA MILIVOJEVIĆ}

grupama omogućila je proveru i dublju interpretaciju rezultata anketnog istraživanja.

\section{Ko su novinari u Srbiji?}

Iako je novinarstvo veoma 'javno zanimanje' nije lako ustanoviti ko su danas novinari u Srbiji. Nakon dvodecenijske devastacije medijskog sektora, čak je i broj novinara potpuna nepoznanica. Poslednji oficijelni podaci odnose se na popis iz 2002. godine, kojim je identifikovano 6148 ,novinara i ostalih publicista" ${ }^{16}$ Nema preciznih kriterijuma na osnovu kojih bi se, iz ovako široko definisanog kruga zanimanja, mogli jasno izdvojiti novinari ili proizvođači informativnih sadržaja. U odnosu na datum popisa, došlo je i do značajnih promena u oblasti medija nakon ulaska prvih stranih investicija u štampane medije 2002. godine i prvih konkursa i početka izdavanja dozvola za emitovanje, 2006. godine. Skorašnji izveštaji o efektima ekonomske krize u medijima procenjuju gubitak od oko $20 \%$ radnih mesta u sektoru samo u periodu 2009/10. Kombinovani indikatori ukazuju da najpribližnija procena ukupnog broja novinara u Srbiji verovatno odgovara broju registrovanih u bazi podataka novinari.rs, koja je u vreme istraživanja imala oko 4000 članova. ${ }^{17}$ Prema istim indikatorima, verovatno je za oko $20 \%$ manji broj onih koji se u užem smislu bave novinarstvom u različitim vrstama medija, približno oko 3200, dok se ostali bave raznim drugim medijskim zanimanjima (montažeri, tonci, kamermani, voditelji i sl).

Nepoznati broj je, međutim, veoma značajan za procenu moći medijske industrije na pragu informacionog društva. U vreme istraživanja, broj medijskih kuća bio je oko 1000 (između 937 i 1072 tokom tromesečnog perioda anketiranja), što svedoči o jako razuđenom sektoru sa velikim brojem uglavnom malih medija. Vrednost tržišta oglašavanja u 2010. godini procenjena je na oko sto sedamdeset i pet miliona evra, što upotpunjuje prilično sumornu sliku visoko zasićenog, kompetitivnog i krajnje fragmentizovanog tržišta punog uglavnom ekonomski teško održivih medija ${ }^{18} \mathrm{U}$ pogledu profesionalnih mogućnosti, većina novinara svakako radi u elektronskim medijima. Prema izveštaju The State of The News Media 2010, koji je uradio Pew Project for Excellence in Journalism, "ostavljajući po strani raznovrsnost platformi, većinu profesionalno proizvedenih informativnih sadržaja i dalje proizvode novinari u štampanim mediji-

16 Strategic Marketing Research (SMR), Novinari i novinarstvo u očima građana i novinara Srbije, Istraživanje rađeno za NUNS 2007, dostupno na zahtev.

17 Podaci iz baze dostupni su na adresi: http://novinari.rs/

18 AGB Nielsen Media Research, Pregled TV scene Srbije 2011, podaci dostupni u istraživačkoj agenciji. 


\section{SNJEŽANA MILIVOJEVIĆ}

ma, ili u onome što bi se danas, verovatno, moglo zvati nešto poput "multiinformativne organizacije sa posebnim naglaskom na štampi"... Novine su naročito ključne u Sjedinjenim Američkim Državama gde tri nacionalne TV mreže zapošljavaju samo 500 novinara, a u industriji štampe..., čak i posle veoma surovih smanjenja broja zaposlenih tokom 2007. i 2008. i dalje radi više od 40.000 stalno zaposlenih novinara. Slično je i u Velikoj Britaniji, gde najveći javni servis zapošljava oko 7000 novinara, dok ih u novinama radi više od $12.000 .{ }^{19}$

Ovaj odnos je u Srbiji drugačiji, ali je bez tačnih podataka teško objasniti dve bitne stvari za budućnost profesije koje iz toga slede. Specifična politička istorija i eksplozija medija tokom 1990-ih, sve veći broj radio i televizijskih kanala i posebno dva velika javna servisa - Radio televizija Srbije (RTS) i Radio televizija Vojvodine (RTV), doprineli su da više novinara radi u elektronskim nego u štampanim medijima. Ali ako je tako, onda zaključak iz liberalnog medijskog modela po kome je 'privatna/komercijalna medijska industrija od centralne važnosti za budućnost novinarstva', u ovim uslovima zahteva dodatno razmatranje. Takođe, istraživanje budućnosti novinarstva bi trebalo promišljati drugačije u medijskoj industriji koja je visoko zavisna od oglašavanja, poput onih u SAD ili Velikoj Britaniji, a drugačije u uslovima u kojima je javni sektor još uvek veoma veliki, kakav je slučaj u Srbiji.

Paradoksalno, jedan od prvih nalaza ovog istraživanja je kako je malo poznato o profesiji čija je dužnost da pomaže drugima da znaju. Čak i nedavno urađena Medijska studija, koju je za Ministarstvo kulture i informisanja pripremio tim EU eksperata, bavila se mogućnostima medijskog razvoja bez preciznih podataka, iako su potpuni demografski podaci o novinarskoj zajednici odlučujući za pravilnu analizu njenih potencijala. ${ }^{20}$ Zato je i rezultate ovog istraživanja teško projektovati na ukupnu profesionalu zajednicu i bolje ih je koristiti kao pokazatelj o istraženoj populaciji. Nju su činili novinari najvećim delom zaposleni u elektronskim medijima (skoro 60\%), u štampi (30\%) ili drugim vrstama medija (novinske agencije, onlajn izdanja, nezavisni novinari) od kojih više od polovina radi u Beogradu, a druga polovina, otprilike ravnomerno, u Vojvodini ili Centralnoj Srbiji. Među njima je više novinarki (51.5\%) nego novinara (43.6\%), a verovatno je da se rodne razlike i povećavaju, jer je veći broj žena u mlađoj profesionalnoj grupi i naročito među studentima

19 citirano prema: Levy D. i Nielsen R. K., The Changing Business of Journalism and its Implications for Democracy, Oxford 2010, str. 3.

20 Tekst Medijske studije na srpskom jeziku (2010), COWI Consortium, http:// www.uns.org.rs/sr-Latn-CS/content/dokumenta/8843/tekst-medijskestudije-na-srpskom-jeziku.xhtml 


\section{SNJEŽANA MILIVOJEVIĆ}

novinarstva, koji tek ulaze u profesionalno polje. Rodna struktura se vidljivo odražava i u raspodeli moći u okviru profesije - među ispitanim vlasnicima/menadžerima žene čine manje od $33 \%$, uglavnom na raznim direktorskim i menadžerskim poslovima, a samo jedna je (su)vlasnica medija. Ovo je uglavnom potvrđeno i u razgovorima u fokus grupama: "Većina ispitanika smatra da je tipičan novinar u Srbiji žena srednjih (tridesetih) godina, a da je novinarstvo tipičan ženski posao kao i svi drugi loše plaćeni poslovi"21.

U pogledu obrazovanja, novinari su visoko obrazovani - 73\% njih ima univerzitetsku diplomu, a preostala četvrtina diplomu srednje škole. To je viši prosek u odnosu na statističke podatke iz 2002. godine, po kojima 56\% novinara i publicista ima univerzitetsko obrazovanje, koji, takođe, ukazuje na veoma obrazovanu profesionalnu grupu. Uobičajeno verovanje o opadajućem nivou obrazovanja novinara kao jednom od uzroka pada kvaliteta i rasta senzacionalizma u medijima, očigledno nije podržano dokazima. Takođe, postoji rašireno mišljenje da samo formalno obrazovanje ne čini dobrog novinara, ali i dalje treba objasniti zašto i javna percepcija i slika koju novinari imaju o sebi tako često uključuje odliku „neobrazovani“. Anketirani novinari su sedam do deset puta obrazovaniji u odnosu na opštu populaciju, u kojoj samo sedam procenata (odnosno $11 \%$, ukoliko se u visoko obrazovanje računa i viša škola) ima univerzitetsku diplomu, što je među najnižim procentima u Evropi. ${ }^{22}$

Rezultati istraživanja ukazuju i na dinamizam u profesionalnom profilisanju. Skoro trećina novinara već oseća uticaj konvergencije jer radi istovremeno za više platformi ili ima još profesionalnih uloga osim novinarske. Visok procenat urednika (37\%) takođe ukazuje da u malim medijskim organizacijama novinari često imaju više profesionalnih odgovornosti istovremeno. Isto važi i za vlasnike i menadžere, od kojih mnogi istovremeno imaju obe uloge ili obavljaju neke druge medijske poslove, jer se samo $22 \%$ njih izjasnilo da obavlja samo jednu ulogu. Najveći broj novinara su stalno zaposleni $(76,5 \%), 16 \%$ radi honorarno a samo $3.8 \%$ su slobodni novinari. Većina anketiranih novinara radi u medijima u privatnom vlasništvu (55.7\%), 37.5\% u javnom/ državnom vlasništvu, a $3.56 \%$ ne znaju tip vlasništva.

21 Milivojević S., Profesija na raskršću, novinarstvo na pragu informacionog društva (2011), str. 147, http://www.fpn.bg.ac.rs/wp-content/uploads/2011/07/ Profesija-na-Raskr\%C5\%A1\%C4\%87u.pdf

22 Uporedi: Svaki peti u Srbiji bez završene osnovne škole, Politika, 19.04.2008, http://www.politika.rs/rubrike/tema-dana/Svaki-peti-u-Srbiji-bez-zavrsheneosnovne-shkole.lt.html 


\section{SNJEŽANA MILIVOJEVIĆ}

\section{Socijalno-ekonomski izazovi}

U mnogim aspektima rezultati istraživanja potvrđuju da su socijalno-ekonomski uslovi glavna prepreka profesionalnom razvoju novinarstva u Srbiji. Kompleksnost trenutne ekonomske situacije se može jasno videti i u okolnostima nastajuće medijske industrije i u odlikama profesije. Mediji su uvek bili važna društvena institucija, ali tek u procesu tranzicije prerastaju i u značajnu industriju. To se dešava u izuzetno teškim uslovima. Prvo, s pravom se ukazuje na to da nekoliko puta odložena privatizacija u stvari ostavlja medije pod političkom kontrolom države. Ali druga i manje istražena posledica odložene privatizacije je činjenica da u medijski sektor nije ušlo dovoljno novog kapitala koji je trebalo da podstakne medijsku ekonomiju u ranim godinama tranzicije. Duga tranzicija je dodatno iscrpela medijske resurse i usporila kreativni razvoj, budući da su mediji mnogo godina preživljavali samo na jeftinoj i nisko kvalitetnoj produkciji, i u potpuno neregulisanom okruženju. Na medijskom tržištu se istovremeno formirala visoko koncentrisana industrija oglašavanja koja postaje novi važan instrument medijske kontrole. Konačno, odložena tranzicija je iscrpela medijske organizacije i učinila ih izuzetno slabim u trenutku kada je svetska ekonomska kriza pogodila Srbiju, krajem 2008. godine.

U pogledu ekonomskog restruktuiranja značajno je da medijske organizacije postaju sve više korporativne, jer prema istraživanju 37\% novinara već radi u domaćim ili međunarodnim korporacijama. Državni/javni sektor je još uvek veliki i isto toliko novinara $(37,5 \%)$ radi u nekom obliku neprivatizovanih medija. Skoro $75 \%$ vlasnika/menadžera potiče iz medija osnovanih tokom 90-tih i njihovo rukovođenje i poslovno umeće stečeno je tokom veoma neregularnih tržišnih i društvenih uslova.

Novinari rangiraju ekonomske probleme medija kao treći na listi važnosti u ovom trenutku (17.23\%), nakon političkih pritisaka $(20.53 \%)$ i niskog kvaliteta novinarstva i dominacije tabloidnog sadržaja (22.13\%). Ali kao najveći problem novinarstva na prvom mestu novinari izdvajaju niske plate (20.36\%). Kada prepoznaju glavne oblike spoljnih pritisaka na medije, uglavnom navode direktne ekonomske instrumente: uskraćivanje finansiranja iz budžeta, nedefinisane kriterijume za pomoć medijima iz državnih ili međunarodnih fondova, uskraćivanje kupovine reklamnog prostora, ometanje distribucije medijskog sadržaja. Prema mišljenju novinara, oni čine čak $40 \%$ najčešćih oblika pritisaka, dok vlasnici ovu grupu problema vide kao još značajniju (54\%). Ali, na pitanje o načinima da se ovakvi uslovi poprave, novinari najčešće navode državnu pomoć (29.4\%) ili strane donacije (25.08\%). Manje od četvrtine njih smatra da bi 


\section{SNJEŽANA MILIVOJEVIĆ}

rešenje bila adekvatnija kreditna politika, dok je među vlasnicima ovaj odgovor izabralo čak $41 \%$ ispitanika.

Ekonomski izazovi koje navode novinari u Srbiji uglavnom nisu povezani sa svetskom ekonomskom krizom, a još manje sa tehnološkim promenama u medijskom svetu. Većina ograničavajućih ekonomskih okolnosti, koje navode, ukazuje na finansijsku i investicionu krizu koja je povezana sa zakasnelom tranzicijom, ravnodušnošću države za medijsku budućnost i odsustvo medijske autonomije (kombinovano 47\%). Tehnološki jaz i zaostalost kao glavni problem medijskog razvoja vidi $4,34 \%$ novinara $\mathrm{i}$ $8,36 \%$ medijskih vlasnika. Ovi rezultati ukazuju da se iz novinarske perspektive još ne razmatraju izazovi koje pred profesiju postavlja nova medijska ekonomija. U tom smislu, sadašnji ekonomski problemi su dvostruko ograničavajući za profesionalni razvoj: prvo, kao skup veoma teških radnih uslova za većinu malo plaćenih, puno opterećenih i uglavnom sindikalno neorganizovanih novinara, i drugo, kao prepreka da se kreativno traga za novim poslovnim modelom i profesionalnim praksama koje on zahteva. Paralisanje novinarskih resursa oko nezavršenih tranzicionih poslova istovremeno ih blokira da se pripreme za buduće ekonomske izazove.

\section{Tehnološki izazovi}

Pored ekonomskih problema, novinari su najosetljiviji kada su u pitanju politički pritisci. Medijska autonomija i nezavisno novinarstvo još uvek su glavni normativni ciljevi i za profesionalne $i$ za regulatorne aktivnosti u Srbiji. Njihova formulacija odražava tranzicione ciljeve, skoro na isti način kao što je to bilo definisano u zemljama Centralne i Istočne Evrope pre dvadeset godina. Istovremeno, ceo kompleks aktuelnih tehnoloških promena rangiran je veoma nisko na listi profesionalnih izazova. Verovatno je delimični uzrok tome redukcionističko shvatanje tehnoloških promena kao običnih, redovnih novina, tipičnih za istoriju masovnih medija. Iz te perspektive, rezultati istraživanja izgledaju kao neočekivani talas optimizma - kao uverenje da tehnološke promene nisu suštinske i da one neće presudno uticati na budućnost profesije.

U praktičnom smislu, tehnološki jaz sa razvijenijim evropskim društvima nije ključni problem, iako podaci ukazuju na ozbiljno zaostajanje kada je u pitanju stepen razvijenosti informacionog društva. Fokus grupni intervjui potvrdili su ove empirijske dokaze i sve diskusije su ukazale na postojanje velikog broja takozvanih "digitalnih podela" unutar medijske zajednice: između centralnih/beogradskih medija i medija u drugim delovima zemlje, između novinara koji i dalje odbijaju da prihvate nove 


\section{SNJEŽANA MILIVOJEVIĆ}

tehnologije i onih čiji rad je u potpunosti zasnovan na korišćenju novih tehnologija, između novinara različitih generacija.

Očigledno je da u kognitivnom smislu, tehnološke promene postavljaju veliki izazov za profesiju. Novinari ispoljavaju veliku samokritičnost u proceni svojih obrazovnih potreba. Samo $11 \%$ njih je reklo da nije imalo nikakvu obuku iz oblasti novih medija, ali uprkos tome $66 \%$ smatra da je novinarima potrebno značajno dodatno obrazovanje, dok samo $27 \%$ vlasnika i menadžera smatra da je novinarima potrebno značajno dodatno obrazovanje. Takođe, ispoljavaju veliku otvorenost za različite forme stalnog usavršavanja, jer samo $6,92 \%$ njih smatra da većina novinara ima odgovarajuće obrazovanje.

U strukturnom smislu, gotovo da nije prisutna nikakva diskusija unutar profesionalne zajednice o promenama i izazovima koje nova tehnologija predstavlja za profesiju. Rezultati pokazuju da većina anketiranih novinara ima pomešana osećanja u odnosu na nove medije: na pitanje kako u svakodnevnom radu dolaze do informacija većini je internet na prvom mestu, ispred intervjua i konferencija za štampu. Ali, kada koriste internet, koriste ga na veoma konvencionalan način okrećući se pouzdanim sajtovima - skoro $65 \%$ njihovih izvora su ili zvanični veb sajtovi (vlada, partija, kompanija) ili sajtovi velikih medija (Rojters, BBC, CNN) i Google vesti. Ostali sadržaji, agregatori sadržaja, uključujući i društvene mreže, uglavnom se koriste samo kao dodatan izvor informacija. Kao što je više puta naglašeno tokom razgovora u fokus grupama, u ovim slučajevima pitanje kredibiliteta dolazi na prvo mesto. Odbrana profesije argumentom kredibiliteta je najčešći vid argumentacije koju novinari koriste "protiv" konkurencije, u vidu građanskog novinarstva i drugih oblika "neprofesionalne" proizvodnje sadržaja. Oni veoma samouvereno veruju da će se profesija promeniti, ali da će preživeti, nasuprot nekim drugim medijskim profesijama kojima ne vide tako izvesnu budućnost. Ukratko novinari veruju da će novinarstvo postati multimedijalno, ali da se neće suštinski promeniti.

\section{Zaključak}

Ovo istraživanje pokazalo je da se novinarstvo u Srbiji nalazi pred prekretnicom koju u ovom trenutku ni ne doživljava kao veliki izazov. Ekonomske teškoće medijske industrije u nastajanju, tipične za tranzicionu zemlju sa ovom vrstom političke kulture, dodatno su pojačane velikom ekonomskom krizom. Nažalost, ekonomski problemi se u domaćem novinarstvu uglavnom redukuju na problem nedovoljnog finansiranja, zbog čega se profesija još ne bavi dubljim ekonomskim prestruktuiranjem, koje već potresa medijski svet. Iz istog razloga, tehnološka revolucija, 


\section{SNJEŽANA MILIVOJEVIĆ}

koja se baš preko informaciono-komunikacionih tehnologija širi ostalim sferama društva, u domaćoj novinarskoj zajednici se ne doživljava kao radikalno novi radni ambijent.

Profesionalnu novinarsku kulturu u Srbiji na pragu informacionog društva određuje specifična kombinacija ekonomskog iscrpljivanja, tehnološke neosvešćenosti i obrazovne samokritičnosti. Prema novinarskoj samopercepciji, najveći na listi medijskih i profesionalnih problema su ekonomske teškoće i politički pritisci. U razgovorima u fokus grupama oni su često definisani u terminima koji i dalje podsećaju na 90-te godine prošlog veka. Usred ove mešavine "starih problema", novinari se suočavaju sa tehnološkim izazovima, ali sa više optimizma, i veruju da njihovi kombinovani praktični, kognitivni i strukturni efekti predstavljaju manje izazove za budućnost novinarstva. Rezultati istraživanja zapravo vode ka zaključku da je novinarstvo u Srbiji u svojevrsnom vakuumu - zaglavljeno između odložene tranzicije i informacionog društva, veoma sporo mobiliše svoje

resurse kao odgovor na dolazeće profesionalne izazove.

\section{LITERATURA:}

Currah A., What's Happening to Our News: An investigation into the likely impact of the digital revolution on the economics of news publishing in the UK, Reuters Institute for the Study of Journalism, Oksford 2009.

Deuze M., National News Cultures: A Comparison of Dutch, German, British, Australian and U.S. Journalist, Journalism and Mass Communication Quarterly, 79(1): 134.49, 2002.

Dobek-Ostrowska B. i Glowacki M., Comparing Media Systems in Central Europe: Between Commercialization and Politicization, University of Wroclaw Press, Wroclaw 2008.

Dutton W. H., The Fifth Estate Emerging through the Network of Networks, Prometheus, Vol. 27, No. 1, 2009, str. 1-15.

Fenton N., New media, old news: journalism \& democracy in the digital age, Sage, London.

Hallin D. C., The Passing of the 'High Modernism' of American Journalism, Journal of Communication, 42:3, 1992, str. 14-25.

Hume E., Cought in the Middle: Central and Eastern European Journalism at a Crossroads, Center for International Media Assistance and National Endowment for Democracy, Washington 2011.

Jakubowicz K., A new notion of media? 1st Council of Europe Conferencee of Ministers responsible for Media and New Communication Services, 28-29 May, Reykjavik Iceland 2009.

Jakubowicz K. i Sukosd M., Finding the Right Place on the Map, Intelect, Bristol UK/Chicago USA 2008. 


\section{SNJEŽANA MILIVOJEVIĆ}

Kepplinger H. M. i Koecher R., Professionalism in the Media World?, European Journal of Communication, 5(2.3): 285.311, 1990.

Levy D. i Nielsen R. K., The Changing Business of Journalism and its Implications for Democracy, Reuters Institute for the Study of Journalism, Oxford 2010.

Lucić J., Vukotić D. i Marković A., Svaki peti u Srbiji bez završene osnovne škole, Politika, 19. april 2008, http://www.politika.rs/rubrike/ tema-dana/Svaki-peti-u-Srbiji-bez-zavrshene-osnovne-shkole.lt.html

Mancini P., Is there a European Model of Journalism?, in: Making Journalists, eds. De Burgh H., London 2005.

Marvin C., When old technologies were new, Oxford University Press, New York 1988.

McQuail D., Journalism as a public occupation: alternative images, in: Democracy, Journalism and Technology: New Developments in an Enlarged Europe, eds. Carpentier N. et al., Tartu University Press, Tartu 2008.

Milivojević S., Television across Europe - regulation, policy and independence-Serbia, in: EUMAP\&Network Media Program, eds. Dragomir M. et al, Budapest 2005, str. 1315-1385.

Milivojević S., Novinarski profesionalizam: Granice medijske autonomje, Gledišta 1-6, 1993, str. 87-95.

Norris P., Driving Democracy: Do Power-Sharing Institutions Work?, Cambridge University Press, Cambridge 2008.

Nezavisno udruženje novinara Srbije, Baza podataka novinara Srbije, http://novinari.rs/

Örnebring H., Comparative European Journalism: The State of Current Research, Reuters Institute for the Study of Journalism, Oxford 2009.

Milivojević S. (ur), Profesija na raskršću - novinarstvo na pragu informacionog društva, Centar za medije i medijska istraživanja, Beograd 2011, http://www.fpn.bg.ac.rs/wp-content/uploads/2011/07/Profesijana-Raskr\%C5\%A1\%C4\%87u.pdf

Pregled TV scene Srbije 2011, AGB Nielsen Media Research, podaci dostupni u istraživačkoj agenciji.

State of the News Media 2010, Annual report on American journalism by Pew Project for Excellence in Journalism, http://www.journalism. org/

Strategic Marketing Reseaech, Novinari i novinarstvo u očima građana i novinara Srbije, Istraživanje rađeno za NUNS, 2007, http://www.anem.rs/sr/medijskaScena/istrazivanja/story/8808/ ISTRA $\%$ C5 $\%$ BDIVANJE+\%E2\%80\%9CNOVINARI+I+NOVINARSTVO+U+O $\% \mathrm{C} 4 \% 8 \mathrm{CIMA}+\mathrm{GRA} \% \mathrm{C} 4 \% 90 \mathrm{ANA}+-$ I+NOVINARA+SRBIJE $\%$ E2\%80\%9D.html

Schudson M., Discovering the News, Basic Books, New York 1978. 


\title{
SNJEŽANA MILIVOJEVIĆ
}

Splichal S. i Sparks C., Journalists for the 21st Century, NJ:Ablex, Norwood 1994.

Schudson M., Why democracies need an unlovable press, Polity Press, Cambridge USA 2008.

Schudson M. i Downie L. Jr., Reconstruction of American journalism, Columbia Journalism Review, October 2009.

Television across Europe: more channels less independence, EUMAP\&Network Media Program, Budapest 2008.

Tekst Medijske studije na srpskom jeziku, COWI Consortium, 2010, http://www.uns.org.rs/sr-Latn-CS/content/dokumenta/8843/tekst-medijske-studije-na-srpskom-jeziku.xhtml

Upotreba informaciono-komunikacionih tehnologija u Republici Stbiji 2009. godine, Republički zavod za statistiku Srbije, http://www.slideshare.net/Shejla/upotreba-informacionp-komunikacionih-tehnologijau-republici-srbiji-2009

Zielonka J. i Mancini P., A media map of Central and Eastern Europe: Executive Summary, 2011, http://mde.politics.ox.ac.uk/images/stories/ summary_mdcee_2011.pdf

Zelizer B., Taking Journalism Seriously: News and the Academy, CA: Sage, BeverlyHills 2004.

Snježana Milivojević

Beograd University, Faculty of Political Sciences

\section{LOW WAGES AND HIGH TECHNOLOGY - JOURNALISTS AND JOURNALISM IN SERBIA}

\begin{abstract}
This paper discusses major findings of the research project "Profession at a Crossroads - Journalism at the Threshold of the Information Society" conducted by the Faculty of Political Sciences, Center for Media and Media Research, from July 2010 to June 2011. The aim of the project was to examine social, economic and technological qualities of the journalist community in Serbia and its capacity to respond to challenges the profession is faced with regarding global media changes and domestic transitional processes. Research results indicate that journalism in Serbia is in a state of limbo and caught between delayed transition and the information society, and that it very slowly mobilizes resources to respond to the forthcoming challenges.
\end{abstract}

Key words: future of journalism, journalism in Serbia, technological challenges to journalism, social and economic status of journalists 